\title{
Effects of Working Capital Management on the Profitability of Thai Listed Firms
}

\author{
Kulkanya Napompech
}

\begin{abstract}
Working capital is needed for day-to-day operations of a firm. The primary purpose of this research was to examine the effects of working capital management on profitability. The regression analysis was based on a panel sample of 255 companies listed on the Stock Exchange of Thailand from 2007 through 2009. The results revealed a negative relationship between the gross operating profits and inventory conversion period and the receivables collection period. Therefore, managers can increase the profitability of their firms by shortening the cash conversion cycle, inventory conversion period, and receivables collection period. However, they cannot increase profitability by lengthening the payables deferral period. The findings also demonstrated that industry characteristics have an impact on gross operating profits.
\end{abstract}

Index Terms-Cash conversion cycle, thailand, working capital.

\section{INTRODUCTION}

Working capital, the money needed for day-to-day operations of a firm, is described as an investment of the firm's capital in current assets and the use of current liabilities to fund part of the investment [1]- [3]. Management of these current assets and current liabilities is important in creating value for shareholders [3], [4]. If a firm can minimize its investment tied up in current assets, the resulting funds can be invested in value-creating projects, thereby increasing the firm's growth opportunities and shareholders' return [2], [3], [5]. However, management can also confront liquidity problems due to underinvestment in working capital [3]. As pointed out by Filbeck and Krueger (2005) [6], the ability of financial managers to effectively manage receivables, inventories, and payables has a significant impact on the success of the business [3]. If capital invested in cash, trade receivables, or inventories is not sufficient, the firm may have difficulty in carrying out its daily business operations [2], [3]. This may result in declining sales and, in the end, a reduction in profitability [2], [7]. Smith (1980) [8] emphasized the trade-off between liquidity and profitability when he argued that working capital management can play an essential role not only in a firm's profitability and risk, but also in its value. Decisions regarding an increase in profitability are likely to involve increased risk, and risk-reducing decisions are likely to result in a reduction in profitability [9]. An accepted measure of working capital management is the cash conversion cycle [9], [10], [12]

Manuscript received October 17, 2011; revised May 02, 2012.

K. Napompech is with the Administration and Management College, King Mongkut's Institute of Technology, Ladkrabang, Bangkok 10520 Thailand (e-mail: knkulkan@kmitl.ac.th, kul1998@yahoo.com). which represents the average number of days between the day the firm begins paying its suppliers and the day it starts to receive cash for products sold [7]. Longer cash conversion cycles mean more time between cash expenditure and cash retrieval [1], [7]. Previous research has used the cash conversion cycle as a measure of working capital management to analyze whether reducing the time allowed for this cycle has positive or negative effects on corporate profitability [1], [7], [9]- [12].

On the whole, empirical evidence related to working capital management and profitability has substantiated the fact that managers can create value for shareholders by shortening the cash conversion cycle to the shortest rational amount of time [3], [7], [10], [11], [13]. The objective of this study was to investigate the relationship between working capital management, as measured through the cash conversion cycle, and corporate profitability in the developing country of Thailand. This study enriches the finance literature on the relationship between working capital management and profitability.

\section{THEORETICAL FoUdATIONS}

Corporations can have a best possible amount of working capital that leads to their value maximization [7]. On the other hand, maintaining a huge inventory, readily granting credit to customers, and being willing to wait a longer time to receive payment may result in higher sales [7]. The downside of granting generous trade credit and maintaining high levels of inventory is that money is stashed in working capital [7]. On the liabilities side, postponing payment to suppliers lets a firm to get the goods prior to paying, therefore increases spontaneous financing and thus reduces the need for costly external funding [7], [14].

Efficient working capital management involves managing short-term assets and short-term liabilities in a way that provides balance between eliminating potential inability to cope with short-term debts and avoiding unnecessary holdings in these assets [5], [15]. Previous research has documented that working capital management influences a firm's profitability [7], [10], [15], [16]. Johnson and Soenen (2003) [17] also reported that efficient working capital management is one of the crucial characteristics of financially flourishing firms. Most of the empirical research into the relationship between working capital management and profitability has confirmed the notion that reducing current assets in comparison to total assets reduces working capital investment; therefore, it would positively affect the firm's profitability. Many scholars have measured working capital using the cash conversion cycle [7], [10], [11], [15]. 
Deloof (2003) [7] analyzed a sample of Belgian firms and found that firms can raise their performance by shortening the periods for receivables collection and inventory conversion. He also reported an unanticipated negative impact associated with the number of days for accounts payable; poorer firms prolong the time to pay their debts. Wang (2002) [16] analyzed a sample of Japanese and Taiwanese firms, Lazaridis and Tryfonidis (2006) [10] examined a sample of firms listed on the Athens Stock Exchange, Nazir and Afza (2007) [3] investigated a sample of firms listed on the Karachi Stock Exchange, and Abuzayed (2012) [12] looked at a sample of firms listed on the Amman Stock Exchange; they all found that shortening the cash conversion cycle enhances firm performance. Shin and Soenen (1998) [4] used a sample of US firms and Erasmus (2010) [2] used a sample of South African firms, and both studies employed the net trading cycle (NTC). NTC is calculated by summing trade receivables and inventories then subtracting accounts payable and expressing the result as a percentage of sales, as the comprehensive measure of working capital management. The results were similar to results of studies that used the cash conversion cycle; the researchers discovered a significant negative relationship between NTC and profitability.

\section{Research Methodology}

The data set in this research was obtained from the Stock Exchange of Thailand. The data include yearly data on sales, cost of goods sold, total assets, financial assets, inventory conversion period, average collection period, payables deferral period, cash conversion period, and debt ratio. The sample consisted of 255 firms that had all the needed data for the three-year period from 2007 through 2009. Therefore, data obtained from this study were panel data on 765 firms' observations. The 255 firms come from 7 industries: industrials, consumer products, technology, agriculture and food, resources, construction and building materials, and service; the number of firms in each sector is shown in Table I.

TABLE I: GROUPING OF INDUSTRIES

\begin{tabular}{|c|c|c|}
\hline $\begin{array}{c}\text { TEQUENCE } \\
\text { NUMBER }\end{array}$ & INDUSTRY & FIRMS \\
\hline 1 & Industrials & 67 \\
\hline 2 & Consumer products & 21 \\
\hline 3 & Technology & 26 \\
\hline 4 & Agro \& Food & 34 \\
\hline 5 & Resources & 15 \\
\hline 6 & Construction \& Building & 44 \\
\hline 7 & Materials & 48 \\
\hline
\end{tabular}

To test the impact of the cash conversion cycle and its components on profitability, the cash conversion cycle, the receivables collection period, the inventory conversion period, and the payables deferral period were regressed against gross operating profit. A non-parametric Spearman correlation was also employed to examine the relationships between the variables used in this research.

To analyze the impact of working capital management on firms' profitability, the gross operating profit (GROSS) was used as the dependent variable. This variable was derived by subtracting the cost of goods sold (COGS) from total sales and dividing the result by total assets minus financial assets. This research, like that of Lazaridis and Tryfonidis (2006)[10], employed GROSS to proxy firms' profitability rather than earnings before interest tax depreciation amortization (EBITDA) or profits before or after taxes. This was because GROSS relates more closely to the cash conversion cycle and its components, various measurements of working capital management.

TABLE II: MEASUREMENT OF VARIABLES AND ABBREVIATION

\begin{tabular}{|c|c|c|}
\hline $\begin{array}{c}\text { Gross Operating } \\
\text { Profits }\end{array}$ & $\begin{array}{c}\text { (Sales - Cost of goods Sold) } \\
\text { /(Total Assets- Financial } \\
\text { Assets) }\end{array}$ & GROSS \\
\hline $\begin{array}{c}\text { Cash Conversion } \\
\text { Cycle }\end{array}$ & $\begin{array}{c}\text { Inventory Conversion Period }+ \\
\text { Receivables Collection Period } \\
\text {-Payables deferral Period }\end{array}$ & CCC \\
\hline $\begin{array}{c}\text { Inventory } \\
\text { Conversion } \\
\text { Period }\end{array}$ & $\begin{array}{c}365 \times \text { (Inventory/Cost of goods } \\
\text { sold) }\end{array}$ & INV \\
\hline $\begin{array}{c}\text { Receivables } \\
\text { Collection Period }\end{array}$ & $\begin{array}{c}365 \times(\text { Accounts } \\
\text { receivables/Sales }\end{array}$ & DSO \\
\hline $\begin{array}{c}\text { Payables deferral } \\
\text { Period }\end{array}$ & $\begin{array}{c}365 \times(\text { Accounts payable/Cost } \\
\text { of goods sold) }\end{array}$ & PAY \\
\hline Firm Size & Natural Logarithm of Sales & LnSales \\
\hline $\begin{array}{c}\text { Fixed Financial } \\
\text { Asset Ratio }\end{array}$ & Fixed Financial Assets / Total \\
\hline assets & FIXEDFA \\
\hline Debt Ratio & Total debt / Total Assets & Debt \\
\hline
\end{tabular}

With regard to the independent variables, working capital management was measured using the cash conversion cycle (CCC). This measure was calculated as inventory conversion period plus receivables collection period minus accounts payables deferral period. Cash conversion cycle is defined as the lag of time between actual expenditures to pay for productive resources and the collection of cash on receivables [18]. The cash conversion cycle, therefore, indicates the average length of time that money is tied up in current assets [18]. A longer time of inventory held and collection of receivables and a shorter time for payments to a firm's creditors imply that cash is being tied up in inventory and receivables and used more speedily in paying off trade payables. If a firm always faces this situation, it will decrease, or squeeze, the firm's available cash. Therefore, a shorter cash conversion cycle reduces a firm's cash needs [19]. Previous researchers have investigated the relationship between cash conversion cycle and firm profitability and found a strong negative relationship [7], [10]. A company's goal should be to shorten its cash conversion cycle to a reasonable minimum time that does not impair operations [18]. The cash conversion cycle can be cut down by reducing the inventory conversion period through processing and selling goods to customers faster, by reducing the receivables collection period through speeding up collections, and by stretching the payables deferral period through slowing down payments to creditors[18]. Therefore, in this research, the cash conversion cycle, the receivables collection period, the inventory conversion period, and the payables deferral period were regressed against gross operating profit to investigate whether a relationship exists between each variable and firm profitability, as shown in regression models (1) through (4). 
The dependent variables included in the analysis were the logarithm of sales as a proxy for firm size. The fixed financial asset ratio (FIXEDFA) was used to assess the impact of non-operating financial assets investments where fixed financial assets means shares and participation of other firms. The debt ratio (DEBT), which is calculated by dividing total debt by total capital, was used to evaluate the influence of long-term capital structure decisions. The formulas and abbreviations used for measurement of all variables employed in the regression models are presented in Table II.

\section{RESEARCH FINDINGS}

\section{A. Descriptive Statistics}

Table III contains the descriptive statistics of the collected variables. The total of observations sums to $n=765$. On average, 5.94 percent of total assets are financial assets (including participation in other subsidiaries). Total sales have a mean of $17,889.57$ million baht, while the median is 2,777.51 million. This shows that the data regarding firm size, which was proxied by logarithm of sales in this research, are quite volatile.

The firms included in this research had an average of 20.75 percent operating profit. Inventory takes on average 124.31 days to sell (43.0 median days). The credit period granted to customers was 61.18 days on average (median 52.0 days), while firms paid their creditors in 52.15 days on average (median 37.12 days). Overall, the average cash conversion cycle was 133.73 days (median 59.03 days).

TABLE III: DESCRIPTIVES STATISTICS OF THE COLLECTED VARIABLES N=

\begin{tabular}{|c|c|c|c|c|c|}
\hline Variable & Median & Mean & $\begin{array}{c}\text { Standard } \\
\text { Deviation }\end{array}$ & Min & Max \\
\hline $\begin{array}{c}\text { FIXED } \\
\text { FA }\end{array}$ & 1.36 & 5.94 & 10.87 & .00 & 83.41 \\
\hline $\begin{array}{c}\text { LNSALE } \\
\text { S }\end{array}$ & 7.93 & 11.31 & 91.35 & 3.70 & $\begin{array}{c}2,534 . \\
23\end{array}$ \\
\hline SALES & $\begin{array}{c}2,777.5 \\
1\end{array}$ & $17,889.57$ & $\begin{array}{c}11,2282 . \\
17\end{array}$ & 40.53 & $\begin{array}{c}200,08 \\
15.8\end{array}$ \\
\hline DEBT & 43.65 & 42.58 & 23.14 & .30 & 157.94 \\
\hline GROSS & 17.61 & 20.75 & 17.46 & -17.9 & 200.69 \\
\hline INV & 43.0 & 124.31 & 305.10 & .00 & $\begin{array}{c}3,413 . \\
14\end{array}$ \\
\hline ARR & 52.0 & 61.18 & 59.34 & .00 & 631.00 \\
\hline PAY & 37.12 & 52.15 & 54.01 & .00 & 502 \\
\hline CCC & 59.03 & 133.73 & 307.21 & -412 & $\begin{array}{c}3751.7 \\
7\end{array}$ \\
\hline
\end{tabular}

\section{B. Correlation Analysis}

Table IV presents Pearson correlations for the variables included in the regression model. The gross operating profit is negatively correlated with the variables of inventory conversion period, receivables collection period, payables deferral period, and cash conversion cycle. This reveals that selling products quicker, collecting money from customers faster, and paying suppliers sooner are all related to an increase in the firm's profitability. These results are consistent with the notion that the shorter the period between production and sale of products, the larger the firm's profitability. Meanwhile the negative relationship between accounts payable and gross profit indicates that less profitable firms postpone their expenses from creditors. Considering the three periods together, the negative correlation points out that the cash conversion cycle is linked with more profitability, which could validate the impact that more efficient management of working capital has on firm profitability.

\begin{tabular}{|c|c|c|c|c|c|c|c|}
\hline & FIXED FA & DEBT & $\begin{array}{c}\text { LN } \\
\text { SALES } \\
\end{array}$ & GROSS & INV & ARR & PAY \\
\hline DEBT & $\begin{array}{c}-.14 \\
.00^{* * *}\end{array}$ & & & & & & \\
\hline $\begin{array}{c}\text { LN } \\
\text { SALES }\end{array}$ & $\begin{array}{l}.021 \\
.565\end{array}$ & $\begin{array}{l}-.06 \\
.09\end{array}$ & & $\begin{array}{c}.376 \\
.00^{* * *}\end{array}$ & & & \\
\hline GROSS & $\begin{array}{c}.10 \\
.00^{* * *}\end{array}$ & $\begin{array}{c}-.13 \\
.00^{* * *}\end{array}$ & $\begin{array}{c}.376 \\
.00^{* * *}\end{array}$ & & & & \\
\hline INV & $\begin{array}{l}-.09 \\
.01 * *\end{array}$ & $\begin{array}{l}.05 \\
.13\end{array}$ & $\begin{array}{l}-.02 \\
.68\end{array}$ & $\begin{array}{c}-.15 \\
.000^{* *}\end{array}$ & & & \\
\hline ARR & $\begin{array}{l}.02 \\
.63\end{array}$ & $\begin{array}{l}-.01 \\
.88\end{array}$ & $\begin{array}{l}-.02 \\
.63\end{array}$ & $\begin{array}{c}-.18 \\
.00^{* * *}\end{array}$ & $\begin{array}{l}.05 \\
.14\end{array}$ & & \\
\hline PAY & $\begin{array}{l}.03 \\
.47\end{array}$ & $\begin{array}{c}.32 \\
.00^{* * *}\end{array}$ & $\begin{array}{l}.002 \\
.96\end{array}$ & $\begin{array}{c}-.09 \\
.01^{* *}\end{array}$ & $\begin{array}{c}.22 \\
.00^{* *}\end{array}$ & $\begin{array}{c}.22 \\
.00^{* * *}\end{array}$ & \\
\hline $\mathrm{CCC}$ & $\begin{array}{c}-.10 \\
.00^{* * *}\end{array}$ & $\begin{array}{c}-.002 \\
.96\end{array}$ & $\begin{array}{l}-.02 \\
.61\end{array}$ & $\begin{array}{c}-.17 \\
.00^{* * *}\end{array}$ & $\begin{array}{c}.97 \\
.00^{* * *}\end{array}$ & $\begin{array}{c}.21 \\
.00^{* * *}\end{array}$ & $\begin{array}{c}.10 \\
.01 * *\end{array}$ \\
\hline
\end{tabular}

\section{Regression Analysis}

To shed more light on the relationship of working capital management and a firm's profitability, regression analysis was employed. The independent variables were fixed financial assets, the natural logarithm of sales, debt ratio, and cash conversion cycle. Industry dummy variables were also included. However, to achieve the minimum degree of freedom necessary, this research used industry categories instead of sectors, which resulted in seven industries: industrials, consumer products, technology, agriculture and food, resources, property and construction materials, and services. A dummy variable was assigned a value of 1 for each of the following industries: industrials, consumer products, technology, agriculture and food, resources, and property and construction materials. Service industry was used as the comparison industry and assigned a value equal to 0 . These variables were included to control for possible industry type effects. Dummy 1, Dummy 2, Dummy 3, Dummy 4, Dummy 5, and Dummy 6 represent industrials, consumer products, technology, agriculture and food, resources, and property and construction materials, respectively.

Table IV presents the results of regression 1 . This model is acceptable from a statistical perspective $(p$-value $=.000)$. The plot of the regression function of this model (Figure 1) also shows that the multiple regression analysis is valid. This regression equation demonstrates that a negative relationship exists between the cash conversion cycle and profitability, which confirms the notion that a decrease in the cash conversion cycle will produce more profits for a firm. The coefficient of the cash conversion cycle variable is negative and highly significant; this implies that an increase in the cash conversion cycle of one day is associated with a decline in gross operating profit of .006 . Moreover, the regression shows that the larger the firm (measured through the natural 
logarithm of sales), the larger the gross operating profits, with a very high level of significance. Gross operating profits statistically decrease as the debt ratio increases. Fixed financial assets have a positive relationship with gross operating profits, but it is not significant. The results also show industry-type effects on profitability. For example, firms in the industrials industry will have smaller gross operating profits than firms in the comparison industry, the service industry, 12.67, if other things in the equation are held constant.

\section{Regression (1)}

GROSS $=28.282+.041$ FIXED FA -.05 DEBT -.006 $\mathrm{CCC}+.073$ LNSALES -12.670 DUM 1 - 1.206 DUM 2 4.180 DUM $3+3.298$ DUM $4-10.824$ DUM5 -10.138 DUM 6

TABLE V: EFFECTS OF WORKING CAPITAL MANAGEMENT ON GROSS OPERATING PROFITS (EQUATION 1)

\begin{tabular}{|c|c|c|c|c|c|}
\hline Predictor & Coef & $\begin{array}{c}\text { SE } \\
\text { Coef }\end{array}$ & $\mathrm{t}$ & $\mathrm{P}$ & $\mathrm{VIF}$ \\
\hline Constant & 28.282 & & 17.188 & $.00^{* * *}$ & \\
\hline FIXED FA & .041 & .026 & .804 & .422 & 1.11 \\
\hline DEBT RATIO & -.050 & -.066 & -2.027 & $.043 * *$ & 1.14 \\
\hline CCC & -.006 & -.103 & -3.043 & $.002 * * *$ & 1.23 \\
\hline LNSALES & .073 & .384 & 12.541 & $.00^{* * *}$ & 1.01 \\
\hline DUM 1 & -12.670 & -.320 & -7.896 & $.00^{* * *}$ & 1.76 \\
\hline DUM 2 & -1.206 & -.019 & -.538 & .591 & 1.34 \\
\hline DUM 3 & -4.180 & -.073 & -1.976 & $.049 * *$ & 1.45 \\
\hline DUM 4 & 3.298 & .064 & 1.739 & $.082 *$ & 1.47 \\
\hline DUM 5 & -10.824 & -.146 & -4.320 & $.00^{* * *}$ & 1.23 \\
\hline \multicolumn{7}{|c|}{ DUM 6 } & -10.138 & -.215 & -5.225 & $.00 * * *$ & 1.52 \\
\hline
\end{tabular}

Analysis of Variance

Sources DF SS MS F P

$\begin{array}{llllll}\text { Regression } & 10 & 69,462.2 & 6,946.2 & 32.0 & .00\end{array}$

Residual Error 754 173,352.4 217.6

Total $764232,814.6$

Durbin-Watson Statistic $=1.80$

R Square $=29.8 \%$ Adjusted R Square $=28.9 \%$

Std. Error of the Estimate $=14.72$

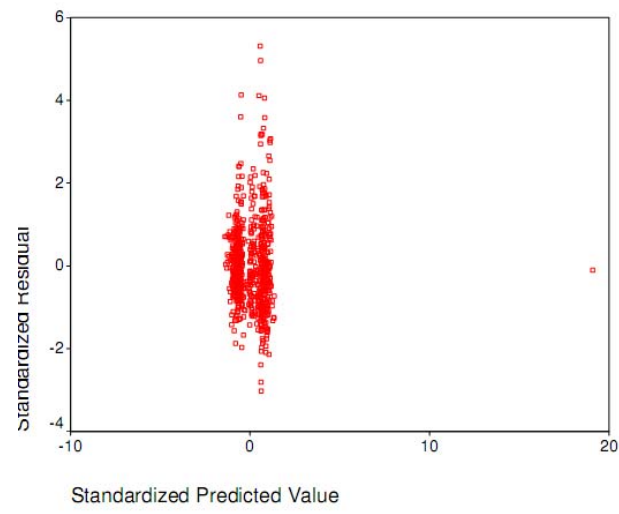

Fig. 1 Plot of regression ( 1)

Table VI presents the results of regression 2. In the second equation, the dependent variable was gross operating profit, and the second equation had the same independent variables as the first. The only difference was the substitution of the cash conversion cycle with the inventory conversion period. This model is acceptable from a statistical perspective ( $p$-value $=.000)$. It is evident from Fig. 2 that the relationships between the variables are linear. These results are consistent with previous research (Deloof, 2003 [7]; Teruel and Solono, 2007 [9]; Lazaridis and Tryfonidis, 2006 [10]; Wang, 2002 [16]) reporting a negative relationship between gross operating profits and inventory conversion period. This does make economic sense; the longer the inventory is held, the more working capital is tied up, and firms thus have less opportunity to invest this capital in profitable projects Therefore, the firm's profitability can be enhanced by speeding up the inventory conversion period.

Regression (2)

GROSS $=27.865+.047$ FIXED FA -.044 DEBT -.004 INV +.074 LNSALES -12.697 DUM 1-1.184 DUM 2-4.298 DUM $3+3.366$ DUM 4 - 10.929 DUM 5 - 10.612 DUM 6

TABLE VI: EFFECTS OF WORKING CAPITAL MANAGEMENT ON GROSS OPERATING PROFITS (EQUATION 2)

\begin{tabular}{|c|c|c|c|c|c|}
\hline Predictor & Coef & $\begin{array}{c}\text { SE } \\
\text { Coef }\end{array}$ & $\mathrm{t}$ & $\mathrm{P}$ & VIF \\
\hline Constant & 27.865 & & 17.016 & $.00^{* * *}$ & \\
\hline FIXED FA & .047 & .03 & .905 & .366 & 1.11 \\
\hline DEBT & -.044 & -.059 & -1.810 & $.071^{*}$ & 1.13 \\
\hline INV & -.004 & -.075 & -2.189 & $.029 * *$ & 1.68 \\
\hline LNSALES & .074 & .385 & 12.539 & $.00^{* * *}$ & 1.01 \\
\hline DUM 1 & -12.697 & -.320 & -7.8888 & $.00^{* * *}$ & 1.76 \\
\hline DUM 2 & -1.184 & -.019 & -.526 & .599 & 1.34 \\
\hline DUM 3 & -4.298 & -.075 & -2.027 & $.043 * *$ & 1.45 \\
\hline DUM 4 & 3.366 & .066 & 1.770 & $.077 *$ & 1.47 \\
\hline DUM 5 & -10.929 & -.147 & -4.350 & $.00 * * *$ & 1.23 \\
\hline DUM 6 & -10.612 & -.225 & -5.394 & $.00^{* * *}$ & 1.86 \\
\hline
\end{tabular}

Analysis of Variance

Sources DF SS MS F P

$\begin{array}{llllll}\text { Regression } & 10 & 68,500.2 & 6,850.0 & 31.4 & .00\end{array}$

Residual Error $754 \quad 174,314.4 \quad 217.9$

Total $764232,814.6$

Durbin-Watson Statistic $=1.805$

R Square $=29.4 \% \quad$ Adjusted R Square $=28.5 \%$

Std. Error of the Estimate $=14.76$

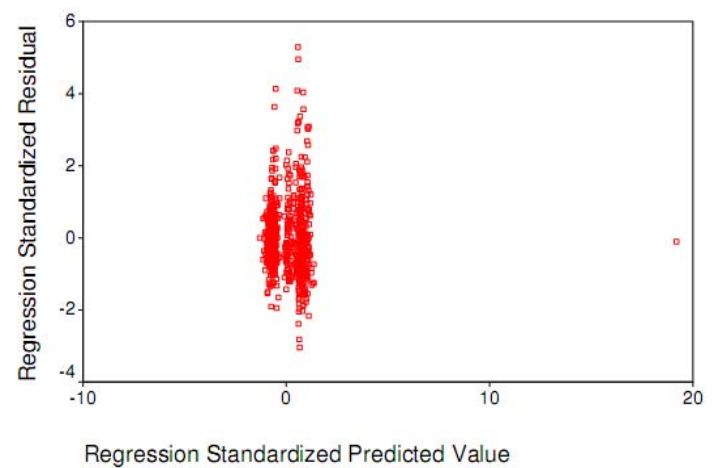

Fig. 2. Plot of regression (2).

Table VII presents the results of regression 3. In the third regression, all variables were the same, except the inventory conversion period was replaced with the receivables collection period. This model is acceptable from a statistical perspective $(p$-value $=.000)$. This is confirmed from the data in Figure 3. Consistent with previous research (Deloof, 2003 [7]; Teruel and Solono, 2007 [9]; Lazaridis and Tryfonidis, 2006 [10]; Wang, 2002 [16]), the third regression revealed a 
negative relationship between gross operating profit and receivables collection period. This indicates that managers can improve profitability by giving their customers a shorter credit period.

Regression (3)

GROSS $=30.758+.067$ FIXED FA -.047 DEBT -.048 DSO +.073 LNSALES -12.684 DUM 1-1.805 DUM 2 3.433 DUM $3+1.883$ DUM $4-11.462$ DUM5 -12.684 DUM 6

TABLE VIII: EFFECTS OF WORKING CAPITAL MANAGEMENT ON GROSS

\begin{tabular}{|c|c|c|c|c|c|}
\hline \multicolumn{7}{l}{ OPERATING PROFITS (EQUATION 3) } \\
\hline Predictor & Coef & SE Coef & $\mathrm{t}$ & $\mathrm{P}$ & VIF \\
\hline Constant & 30.758 & & 17.863 & $.00^{* * *}$ & \\
\hline FIXED FA & .067 & .041 & 1.312 & .190 & 1.10 \\
\hline DEBT & -.047 & -.062 & -1.933 & $.054 *$ & 1.13 \\
\hline DSO & -.048 & -.16 & -5.232 & $.00^{* * *}$ & 1.05 \\
\hline LNSALES & .073 & .382 & 12.615 & $.00^{* * *}$ & 1.01 \\
\hline DUM 1 & -12.684 & -.320 & -7.999 & $.00^{* * *}$ & 1.76 \\
\hline DUM 2 & -1.805 & -.028 & -.814 & .416 & 1.34 \\
\hline DUM 3 & -3.433 & -.060 & -1.637 & .102 & 1.46 \\
\hline DUM 4 & 1.883 & .037 & .993 & .321 & 1.50 \\
\hline DUM 5 & -11.462 & -.155 & -4.627 & $.00 * * *$ & 1.23 \\
\hline DUM 6 & -12.684 & -.269 & -7.093 & $.00 * * *$ & 1.58 \\
\hline$* * * *$ significant at the $1 \%, 5 \%$, and $10 \%$ levels, respectively
\end{tabular}

Analysis of Variance

Sources DF SS MS F P

$\begin{array}{llllll}\text { Regression } & 10 & 73,249.9 & 7,325.0 & 34.6 & .000\end{array}$

Residual Error 754 159,564.7 211.6

Total $764232,814.6$

Durbin-Watson Statistic $=1.775$

R Square $=31.5 \%$ Adjusted R Square $=30.6 \%$

Std. Error of the Estimate $=14.54$

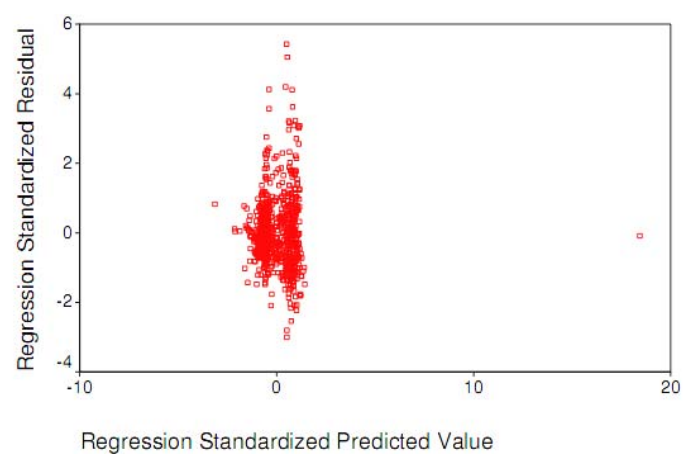

Fig. 3. Plot of regression (3).

Table VII presents the results of regression 4. In the last regression, the same variables were used, except inventory conversion period, which was replaced with accounts payable. This model is acceptable from a statistical perspective ( $p$-value $=.000)$. Figure 4 also shows that the multiple regression analysis is suitable. A negative relationship exists between gross operating profit and the accounts payables deferral period, which contradicts the notion that the longer a firm delays its payments, the higher level of working capital it stores and uses with the intent of increasing profitability. This difference may exist because less profitable firms take longer to pay their obligations. This negative relationship confirms the negative correlation between gross operating profits and the accounts payable deferral period presented in Table 4. However, this result is not statistically significant, but it is consistent with previous research (Charitou, Elfani, and Lois, 2010 [1]; Deloof, 2003 [7]).

Regression (4)

GROSS $=27.698+.061$ FIXED FA -.036 DEBT RATIO -.009 PAY +.074 LNSALES -12.794 DUM 1-1.329 DUM2 - -4.399 DUM 3+ 3.157 DUM 4 - 11.240 DUM5 -12.183 DUM 6

TABLE VII: EFFECTS OF WORKING CAPITAL MANAGEMENT ON GROSS OPERATING PROFITS (EQUATION 4)

\begin{tabular}{|c|c|c|c|c|c|}
\hline OPERATING PROFITS (EQUATION 4) \\
\hline Predictor & Coef & SE Coef & $\mathrm{t}$ & $\mathrm{P}$ & VIF \\
\hline $\begin{array}{c}\text { FIXnstant } \\
\text { FA }\end{array}$ & 27.698 & & 16.784 & $.00^{* * *}$ & \\
\hline DEBT & .061 & .038 & 1.182 & .238 & 1.10 \\
\hline PAY & -.009 & -.03 & -.849 & .396 & 1.11 \\
\hline LNSALES & .074 & .386 & 12.542 & $.00^{* * *}$ & 1.01 \\
\hline DUM 1 & -12.79 & -.323 & -7.931 & $.00^{* * *}$ & 1.76 \\
\hline DUM 2 & -1.329 & -.021 & -.589 & .556 & 1.34 \\
\hline DUM 3 & -4.399 & -.076 & -2.068 & $.039 * *$ & 1.45 \\
\hline DUM 4 & 3.157 & .062 & 1.639 & .102 & 1.50 \\
\hline DUM 5 & -11.240 & -.152 & -4.433 & $.00^{* * *}$ & 1.24 \\
\hline DUM6 & -12.193 & -.028 & -6.695 & $.00^{* * *}$ & 1.58 \\
\hline
\end{tabular}

$* * *, * *, *$ significant at the $1 \%, 5 \%$, and $10 \%$ levels, respectively

Analysis of Variance

Sources DF SS MS F P

$\begin{array}{llllll}\text { Regression } & 10 & 67,613.8 & 6,761.4 & 30.9 & .000\end{array}$

Residual Error $754 \quad 175,200.8 \quad 210.1$

Total $764232,814.6$

Durbin-Watson Statistic $=1.80$

R Square $=29.0 \quad \%$ Adjusted R Square $=28.1 \quad \%$

Std. Error of the Estimate $=14.80$

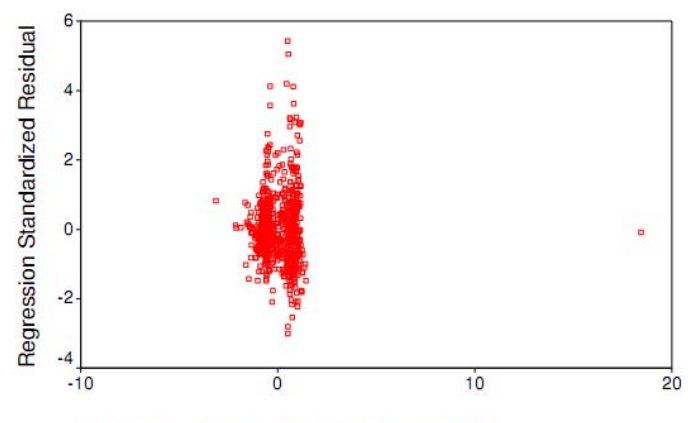

Regression Standardized Predicted Value

Fig. 4. Plot of regression (4).

The multicollinearity test showed that all regression models have the variance inflation factor (VIF), a tool to verify whether one independent variable has a high correlation with the remaining independent variables ranging between 1 and 1.9, which is less than 10 , thereby demonstrating that no multicollinearity exists between independent variables in the regression models [10], [20].

\section{DISCUSSION}

The results of this research are similar to those found in previous studies (Shin and Soenen, 1998 [4]; Deloof, 2003 [7]; Wang, 2002 [16]) and the analysis performed 
substantiated the essential role of working capital management in value creation of firms by shortening the cash conversion cycle. However, the findings of this research confirmed that only two actions can increase profitability: reducing the inventory conversion period by producing and selling goods faster and reducing the receivables collection period by accelerating collections. The results of this study showed a significant negative relationship between firm profitability and the inventory conversion period and receivables collection period. This study also found an inverse relationship between the payables deferral period and profitability, which may be a result of less profitable firms taking longer to pay their suppliers. This is consistent with Deloof (2003) [7]; however, this result is not significant. This study also illustrated industry type effects on profitability.

\section{REFERENCES}

[1] M. Charitou, M. Elfani, and P. Lois, "The Effect of Working Capital Management On Firm's Profitability: Empirical Evidence From An Emerging Market," Journal of Business \& Economics Research, vol. 8, No. 12, pp. 63-68, Dec 2010.

[2] P. Eramus, "The Relationship Between Working Capital Management and Profitability for south African Listed Industrial Firms," The Business Review, Cambridge, vol. 15, no. 1, pp. 183-188, Summer 2010.

[3] M. S. Nazir, and T. Afza., "Working Capital Requirements and the Determining Factors in Pakistan," The IUP Journal of Applied Finance, vol.15, no. 4, pp. 28-38, 2009.

[4] H. H. Shin, and L. Soenen, "Efficiency of Working Capital and Corporate Profitability, "Financial Practice and Education, vol. 8, no. 2, pp. 37-45, Fall/Winter, 1898.

[5] N. Mohamad, and N. Saad, "Working Capital Management: The Effects of Profitability in Malaysia," International Journal of Business, vol. 5, no. 11, pp. 140-147, November, 2010.

[6] G. Filbeck and T. Krueger, "Industry Related Differences in Working Capital Management" Mid-American Journal of Business, vol. 20, no. 2, pp. 11-18, 2005.

[7] M. Deloof, "Does Working Capital Management Affect Profitability of Belgian Firms?" Journal of Business Finance and Accounting, vol. 30, no. $3 \& 4$, pp. 573-587. 2003.

[8] K. Smith, "Profitability versus Liquidity Tradeoffs in Working Capital Management," in Readings on the Management of Working Capital, West Pulishing Company, St. Paul, New York, 1880.

[9] P. J. Garcia-Teruel and P. Martínez-Solono, "Effects of Working Capital Management on SME Profitability," International Journal of Managerial Finance, vol. 3, no. 2, pp. 174-177, 2007.
[10] I. Lazaridis and D. Tryfonidis, "Relationship Between Working Capital Management and Profitability of Listed Companies in the Athens Stock Exchange," Journal of Financial Management and Analysis, vol. 18, no. 1, pp. 26-35, 2006.

[11] A. Raheman, and M. Nasr, "Working Capital Management and Profitability-Case of Pakistan Firms," International Review of Business Research Papers, vol., no.1, pp. 279-300 , 2007.

[12] B. Abuzayed, "Working capital management and firm's performance in emerging markets: the case of Jordan," International Journal of Managerial Finance, vol. 8, no. 2, pp. 155-179, 2012

[13] S. Banos-Caballero, P. Garcia-Teruel, and P. Martinez-Solano, "Working capital management in SMEs," Accounting and Finance, vol. 50, no. 3, pp. 511-527, 2010.

[14] W. R. Lasher, "Financial Management: A Practical Approach," Thomson South-Western, ch. 17, pp. 630, 2008

[15] A. M. A. Eljelly, "Liquidity-Profitability Tradeoff: An Empirical Investigation in An Emerging Market," International Journal of Commerce \& Management, vol. 14, no. 2, pp. 48-60, 2004.

[16] Y. J. Wang, "Liquidity Management, Operating Performance, and Corporate Value; Evidence From Japan and Taiwan," Journal of Multinational Financial Management, vol. 12, pp. 159-179, 2002.

[17] R. Johnson, and L. Soenen, "Indicators of Successful Companies," European Management Journal, vol. 21, no. 3, pp. 364-369, 2003.

[18] E. F. Brigham, and M. C. Ehrhardt, Financial Management: Theory and Practice, 11 st ed. USA: South-Western, ch.22, pp. 742-782, 2005.

[19] W. Drobetz and C. Gruninger, "Corporate cash holdings: Evidence from Switzerland," Fin Mkts Portfolio Mgmt, vol.21, pp. 293-324, 2007.

[20] S. Sumaedi, I. G. M. Y. Bakti, and N. Metasari, "The Effects of Students' Perceived Service Quality and Perceived Price on Student Satisfaction," Management Science and Engineering, vol. 5, no. 1, pp. 88-97, 2011

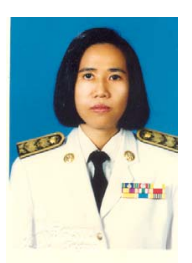

KulkanyaNapompech was born in Bangkok, Thailand. She received a BA in cost accounting from Chulalongkorn University, Thailand, in 1985. She received an MBA in business administration from the University of Central Missouri, USA, in 1987 and received a DBA from Louisiana Tech University, USA, majoring in finance, in 2002.

She is an associate professor at Administration and Management College, King Mongkut's Institute of Technology, Ladkrabang (KMITL), Thailand. She has published articles in Managerial Finance, International Journal of Business, Accounting, International Journal of Business and Economics Perspectives, and International Journal of Arts and Sciences. Her current research interests include dividend policy, working capital management, and consumer behavior. 